\title{
QUEIMARAM NOSSA CASA NA JURÉIA!
}

\author{
Paulo Cesar Franco \\ Associação dos Jovens da Juréia (AJJ), Brasil. \\ pcfranco15@gmail.com
}

\begin{abstract}
RESUMO
Este texto é uma narrativa a respeito das diferentes faces da atuação do poder colonial sobre as comunidades tradicionais caiçaras da Juréia, Iguape, litoral sul do Estado de São Paulo. Instalado no Brasil sob o pretexto da cristandade, o colonialismo perpassou os séculos e floresceu com vigor na década de 1950 nas comunidades caiçaras sob a ação violenta das grilagens empreendidas pelos especuladores imobiliários que usavam capangas a cavalo para intimidar os nativos e queimar suas casas. No início dos anos de 1980, a roupagem colonialista se utilizou da estratégia militar para acossar os caiçaras em seus territórios através da ameaça da implantação das usinas nucleares, Angra 3 e 4 pela empresa Nuclebrás, convênio Brasil- Alemanha. A partir de meados de 1986 é decretada a Estação Ecológica da Juréia sobre o Território Caiçara de onde expulsou, pelo cansaço, dezenas de famílias para as periferias das cidades do Vale do Ribeira e Baixada Santista. As queimadas das casas dos caiçaras pelos especuladores de terras não acabaram, atualmente a Fundação Florestal dá continuidade na logística colonizadora destruindo as casas dos moradores nativos da Juréia (Rio Verde e Grajaúna) e dissemina a narrativa de que essas populações não são tradicionais. Enfim, mudou-se o forro do sofá, mas a estrutura colonial continua a mesma!
\end{abstract}

Palavras-chave: Comunidades caiçaras. Juréia (São Paulo). Colonialidade.

Para mim, tem sido sempre um mistério o fato de alguns homens se sentirem gratificados pela humilhação de seus semelhantes (GANDHI).

\section{INTRODUÇÃO}

As comunidades tradicionais caiçaras do Grajaúna e Rio Verde estão situadas no município de Iguape, na região do Vale do Ribeira, litoral sul do Estado de São Paulo. São populações nativas que habitam o Território Caiçara, espaço litorâneo que se estende do Estado do Paraná até o Estado do Rio de Janeiro. Nessa faixa, a partir do século XVI, começou a ser gestado o povo caiçara. O encontro do invasor europeu com o indígena e posteriormente com o negro deu origem ao brasileiro caiçara, pois conforme Ribeiro "surgimos da confluência, do entrechoque e do caldeamento do invasor português com índios silvícolas e campineiros e com negros africanos, uns e outros aliciados como escravos" (RIBEIRO, 1995, p. 19). 
A partir do século XVII, por meio do rio Ribeira de Iguape, os colonizadores foram adentrando mais planejadamente para o interior do continente em busca de ouro de aluvião que eram encontrados nas margens dos rios. Em 1630 foi instalada em Iguape a Casa da Oficina Real de Fundição de Ouro, onde foi fundido o primeiro ouro de aluvião em terras brasileiras (PEREIRA JUNIOR, 2005, p. 26). Esse período, que ficou registrado na história de Iguape como o primeiro ciclo econômico, atraiu parte da população, que realizava serviços ligados à extração do ouro, trabalhos no porto marítimo e as primeiras construções de casas de taipas e de paredes de pedras, para as redondezas da cidade.

O segundo ciclo econômico foi a produção do arroz que para o historiador Iguapense, Roberto Fortes, foi

a fase econômica mais importante foi a do ciclo do arroz, que começou a se firmar em fins do século XVIII e atingiu seu esplendor na primeira metade do século XIX, quando capitalistas abastados ganharam expressivos lucros com essa cultura. Nessa época, construíram-se os mais imponentes casarões de pedra e cal que, até hoje, ornamentam a Praça da Basílica e cercanias. (FORTES, 2000, p. 52).

Com as decadências dos ciclos econômicos, sobretudo da produção arrozeira que dispersou os fazendeiros para outros estados, a população que dependia dos donos de engenhos foi se deslocando para regiões afastadas do centro urbano onde encontravam terras férteis, rios com abundância de peixes, encostas de morros e beiras de praia propícias para a estabelecimento das comunidades tradicionais caiçaras.

Conforme Diegues, os caiçaras vivendo no interstício da Mata Atlântica e do mar, estuários, mangues, restingas e lagunas, usando seus recursos naturais para a reprodução de seu modo de vida, construíram um território rico em diversidade biológica e cultural (DIEGUES, 2007, p. 17) que permitiu a diversidade biológica e cultural do povo caiçara de modo que se consolidasse ao longo dos séculos um modo social de organização conhecido por mutirão de fandango.

\section{MUTIRÃO DE FANDANGO}

O Mutirão de fandango, enquanto organização social, é "uma manifestação cultural popular que reúne dança, música e possui regras estéticas definidas. Em cada localidade, entretanto, 
existem características específicas, criando assim uma realidade artística rica e variada" (GRAMANI; PIMENTEL; CORREA, 2006, p. 21).

O mutirão de fandango começa quando o chefe de família define um corte de roça. O corte de roça é o terreno que a família caiçara prepara para plantar a maniva da rama onde se formará uma roça de mandioca. A família, por meio do chefe da casa, faz a derrubada das árvores usando todo o conhecimento tradicional que é passado de geração para geração. Faz-se contato com a terra em período de lua minguante e com o uso de uma foice derruba-se as árvores pequenas e na sequência utiliza-se o machado para derrubar as árvores maiores. Vencido o corte da roça, ou seja, a área a ser utilizada para o plantio da rama, todas as árvores são picadas - cortadas em pedaços bem pequenos - para facilitar a queimada. Após quinze dias da derrubada é feito um aceiro em torno da roça para o fogo não entrar na mata. Coloca-se fogo nas árvores picadas queimando as folhas e os galhos menores restando os galhos maiores. Depois vem a coivara, ou seja, a retirada dos galhos maiores que são depositados nas beiradas da roça para serem usados como lenha. Feito todo o trabalho de limpeza do terreno, marca-se o mutirão para que os amigos venham ajudar no plantio da roça.

Em pleno trabalho braçal, os cavadores vão abrindo as covas em ritmo rápido até o meio da roça. Depois passam para o outro lado e repetem a cavação até chegar à outra extremidade onde se conclui o trabalho.

Vários saberes são movimentados durante o processo do mutirão. Começando pela cavação, a enxada usada para fazer as covas é diferente da que se usa para carpir. A enxada de carpir pode ter os cantos (extremidade da enxada), ser pequena e o cabo além de ser mais longo pode ter uma inclinação mais aguda. Já a enxada para cavar é preciso ser grande, sem cantos e com inclinação mais leve. Esses detalhes, que parecem desprezíveis, são fundamentais na hora do trabalho. No momento da cavação, por exemplo, a ausência dos cantos na enxada evita que o cavador machuque seu companheiro no caso de a enxada bater numa raiz e ser desviada para o lado e atingir a perna do parceiro.

Além dos saberes que se observam na cavação, também é possível verificar os saberes no ato de plantar as manivas das ramas. Elas são pedaços da rama da mandioca são fincadas nas covas onde brotam, mas para isso é necessário que sejam fincadas de "olho para cima", ou seja, com a ponta para terra e nunca o contrário senão não há brotação. No final da tarde a roça se encontra 
cultivada completamente. O retorno para a casa do chefe de família é sempre com satisfação e alegria pelo serviço realizado (FRANCO, 2015, p. 75).

Até meados da década de 1980, em algumas comunidades tradicionais, como era o caso da Cachoeira do Guilherme, região conhecida por “Coração da Juréia” (MELO, 2000, p. 04), antes de iniciar o baile de fandango pelo líder falecido, Sátiro Tavares, era realizava a reza do mês, quando as pessoas eram curadas com o uso de remédios obtidos das ervas medicinais da Mata Atlântica.

À noite acontecia o baile de fandango propriamente dito. Os violeiros tocavam e cantavam as modas que falavam do cotidiano caiçara. As crianças aprendiam com os mestres o manuseio dos instrumentos musicais que eram a viola fandangueira e a rabeca. As mulheres aguardavam no banco o convite dos cavalheiros para irem dançar no meio do salão. Na cozinha, uma equipe preparava o café da madrugada com as comidas típicas que eram compartilhadas numa mesa comum. O ritmo envolvente do fandango seguia noite adentro e chegava até o amanhecer. No clarear do dia, o chefe de família agradecia o trabalho coletivo e alguém anunciava novo mutirão de fandango em outra comunidade vizinha.

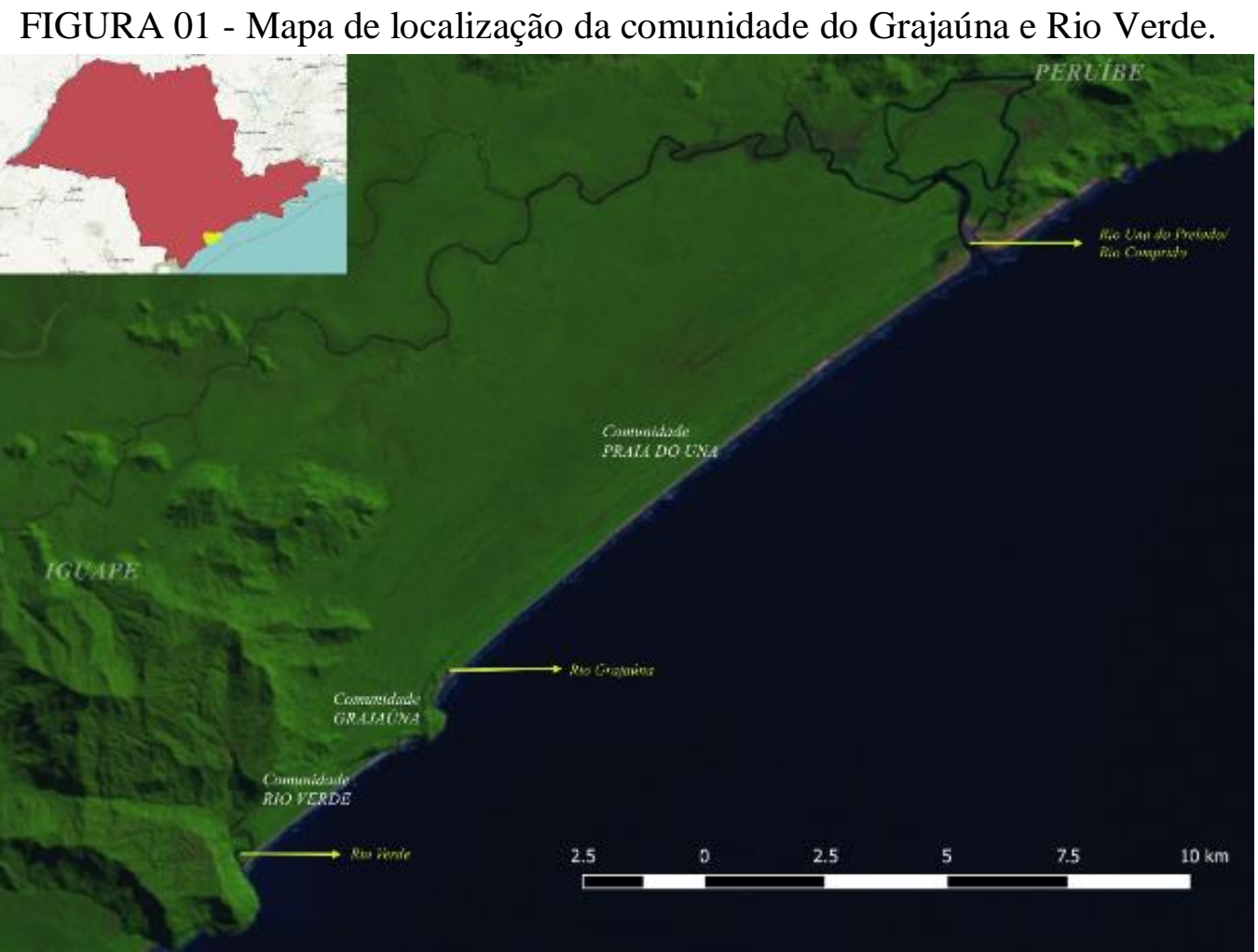

Fonte: Heber do Prado Carneiro. 
O mutirão de fandango, que ocorria com frequência nas comunidades tradicionais caiçaras da Juréia, reduziu-se atualmente às comunidades do Grajaúna e Rio Verde, onde ainda exerce um papel de educação popular potente, pois como salienta Brandão:

O saber da comunidade, aquilo que todos conhecem de algum modo; o saber próprio dos homens e das mulheres, de crianças, adolescentes, jovens, adultos e velhos; o saber de guerreiros e esposas; o saber que faz o artesão. [...] Os que sabem: fazem, ensinam, vigiam, incentivam, demonstram, corrigem, punem e premiam. Os que não sabem espiam, na vida que há no cotidiano, o saber que ali existe, vêem fazer e imitam, são instruídos com o exemplo, incentivados, treinados, corrigidos, punidos, premiados e, enfim, aos poucos aceitos entre os que sabem fazer e ensinar, com o próprio exercício vivo de fazer. (BRANDÃO, 2007, p. 22).

O modo de vida caiçara fundamentado no mutirão de fandango perdurou com vivacidade até meados da década de 1980, período que teve início na região da Juréia as investidas das Unidades de Conservação da Natureza que se impuseram com pautas voltadas às políticas ambientais de cunho racista.

Para efeito de conhecimento do período cronológico das comunidades caiçaras, Sanches divide em quatros momentos intituladas de tempos. A saber: "O Tempo dos Antigos", "O Tempo da Caxeta ou o Tempo do Palmito", “O Tempo da Nuclebrás" e o "Tempo da Ecologia" (SANCHES, 2004, p. 59).

\section{O TEMPO DOS ANTIGOS}

A partir de meados da década de 1950, período caraterizado por Tempo dos Antigos, baixou uma legião de grileiros na Juréia, Iguape/SP, com objetivo de açambarcar terras de caiçaras para transformá-las em balneários especulativos. A maioria das famílias tradicionais foram vítimas desse ímpeto capitalista que chegou com o empresariado interessado nas terras litorâneas para obtenção do lucro fácil. Os doutores da cidade levavam o cartório nas casas dos caiçaras e ludibriavam os anciãos que borravam o dedo na "almofadinha" onde consolidavam o ritual do "preto no branco" passando aos grileiros as suas terras a preço de banana. Grande parte das famílias caiçaras nunca receberam qualquer valor em dinheiro nesse processo violento de açambarcamento especulativo do território caiçara. 
Meus pais foram vítimas desses grileiros que chegaram imponentes, bem vestidos e com olhares de poder. O tempo foi breve para lançarem fogo na casa de meus pais. Começaram pelo telhado de palha que rapidamente se alastrou pela moradia inteira. Em pouco tempo o lar deles havia se tornado cinza. Tudo foi queimado em nome do lucro, da especulação, da ganância do capital. "Do terreiro da nossa casa, eu enxergava minhas roupinhas arderem em meio as chamas que devoravam nossa morada. É uma lembrança terrível daquele tempo de adolescente. Nós seguimos desorientados para casa de parentes que nos acolheram" (PUPP, 2021). A pergunta era: Para onde ir? A quem recorrer? Como superar a angústia da violência sofrida?

FIGURA 02 - Ilustração sobre três momentos históricos: Tempo da especulação imobiliária (grilagens de terras); Tempo da Nuclebrás (ditadura militar) e Tempo da ecologia (derrubadas das casas caiçaras).

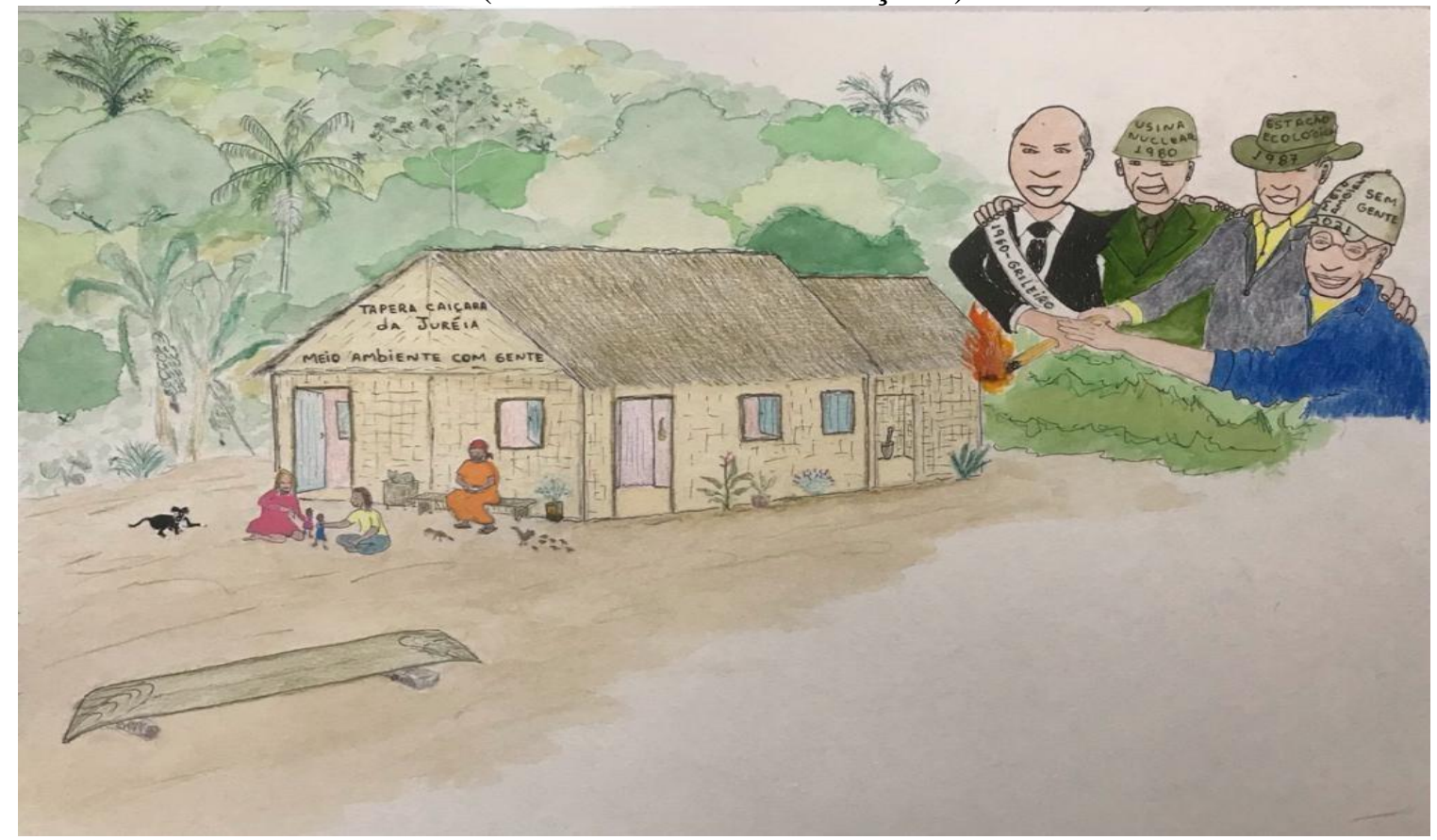

Fonte: Wanderlei Ribeiro (DECO).

Partiram para longe, em busca de amparo nas casas de parentes no interior da Juréia. De casa em casa, buscando um lugar para se estabelecer, não bastasse a violência sofrida pelos especuladores, meus pais continuaram sofrendo devido ao falecimento de minha irmã de três anos que se acidentou no fogo à lenha. Ela sofreu queimadura profunda e foi levada para um hospital na cidade de Santos onde meus pais não tinham condições de acompanhá-la. Por lá, possivelmente minha irmã foi sepultada como indigente! Suportar a perda de um lar e a perda de um ente querido 
fez dos corações de meus pais um território de sentimentos silenciados, calados! Este meu escrito é, em parte, uma tentativa de desenterrar um grito calado de minha mãe, um suspiro abafado de meu pai e uma angústia sem espaço para as vozes de meus irmãos...

Eu nasci na Juréia no ano 1973, período que meus pais haviam voltado para o território de origem e estavam se reestabelecendo da rasteira sofrida pela grilagem que havia queimado a nossa casa. Passado um tempo, começou a chegar a notícia da Usina Nuclear. Nova insegurança começou a rondar o território caiçara. Iniciava-se uma nova onda de restrições, indefinições e medo... Com os debates para implantação da Usina Nuclear na Juréia apareceram os pseudo ambientalistas. Estes foram e continuam sendo os piores açambarcadores dos caiçaras da Juréia, pois grande parte deles continua encastelado no governo paulista e em instituições que defendem a superada ideia de preservação da "natureza sem gente".

Os ambientalistas chegaram sorrateiramente nas casas dos caiçaras pedindo cafezinho com bolo de chuva. Entrevistavam os mais velhos e usavam o conhecimento tradicional para embasar pesquisas científicas, mas não contemplavam o saber cultural como elemento integrante do território tradicional. "Batiam nas costas dos caiçaras e pregavam a falaciosa retórica de que a Juréia seria um Santuário Ecológico onde os caiçaras voltariam a viver em harmonia com a natureza" (PRADO, 2020). Através dos sofismos distribuíam santinhos do Bom Jesus de Iguape para convencer os nativos no processo de apoio ao movimento ambientalista que, ao longo dos anos, se transformou num racismo ambiental ${ }^{1}$ que até hoje oprime e destrói as casas das famílias tradicionais do Rio Verde e Grajaúna.

\section{TEMPO DA ECOLOGIA}

Com a implantação da Estação Ecológica da Juréia, em 1986, o Território Caiçara da Juréia foi sobreposto por um modelo de Unidade de Conservação que expulsou centenas de famílias tradicionais para as periferias das cidades do Vale do Ribeira e Baixada Santista causando a definitiva perda da identidade dos mestres artesãos fandangueiros que herdaram saberes de experiências de seus ancestrais. A narrativa de que os caiçaras viveriam num Santuário Ecológico

\footnotetext{
${ }^{1}$ Moradias foram demolidas em julho de 2019 pela Fundação Florestal de São Paulo, gestora de unidade de conservação criada sobre território tradicional de comunidades caiçaras. Disponível em: 〈https://www.socioambiental.org/pt-br/tags/Juréia >. Acesso em: 06/10/2021.
} 
serviu bem como uma narrativa persuasiva veiculada pelos emergentes pseudo ambientalistas do capital.

A Estação Ecológica mais uma vez expatriou meus pais do Território Caiçara da Juréia. Dessa vez eu estava junto e tinha 12 anos de idade. Fomos aos poucos silenciados em nosso próprio lugar. Primeiro proibiram a nossa roça de mandioca, depois dificultaram a limpeza das trilhas, mais tarde impediram a reforma das nossas casas e, por último, disseram que nós éramos estorvos e que deveríamos deixar nossa casa novamente, pois eles iriam preservar a Mata Atlântica. Chegava o tão odiado Tempo da Ecologia!

Até aqui dediquei-me ao registro de minha história de caiçara dentro da Juréia. Fiz isso com objetivo de contextualizar minha experiência enquanto ser tradicional que ouviu de meus pais e parentes e viveu a opressão dos poderosos, sob o uso de diferentes estratégias, para impedir que vivêssemos em nosso território de origem, em nosso habitat natural. Por essa razão me reportei ao título desse artigo intitulando-o "TESTEMUNHO: QUEIMARAM NOSSA CASA NA JURÉIA! A colonização é semelhante a reforma de um sofá: muda-se o forro, mas a estrutura permanece e mesma!".

O processo da queima da casa dos meus pais na Juréia ainda não acabou. Continua existindo... Por outros meios, os açambarcadores de caiçaras continuam desabitando, COLONIZANDO os moradores tradicionais.

Em 2019, conforme foi amplamente divulgada pela mídia alternativa, pois a mídia "oficial” está a serviço do poder, assistiu-se a criminosa destruição das casas dos moradores das comunidades tradicionais do rio Verde e Grajaúna. Os casais Heber e Vanessa, Marcos e Daiane tiveram suas casas friamente, e sem ordem judicial, destruídas pela Fundação Florestal que utilizou a polícia para amparar a colonização em vez de proteger as famílias. Eles querem expulsar os caiçaras para capitalizar o mar, a praia, a mata, a flora, a fauna. Eles fazem isso com o ímpeto opressor dos colonizadores do século XVI. Eles fazem isso com os olhares dos grileiros da década de 1950 que enxergavam no território caiçara a possibilidade do lucro. Eles fazem isso com os olhares dos ditadores militares que viam na Juréia a possibilidade da implantação das usinas nucleares. Hoje, eles continuam olhando para a Juréia com o ímpeto da privatização, da possibilidade de empresas de seus interesses explorarem as essências do território que o caiçara sempre preservou. 
FIGURA 03 - Celebração em torno da destruição das casas no Rio Verde, em 2019.

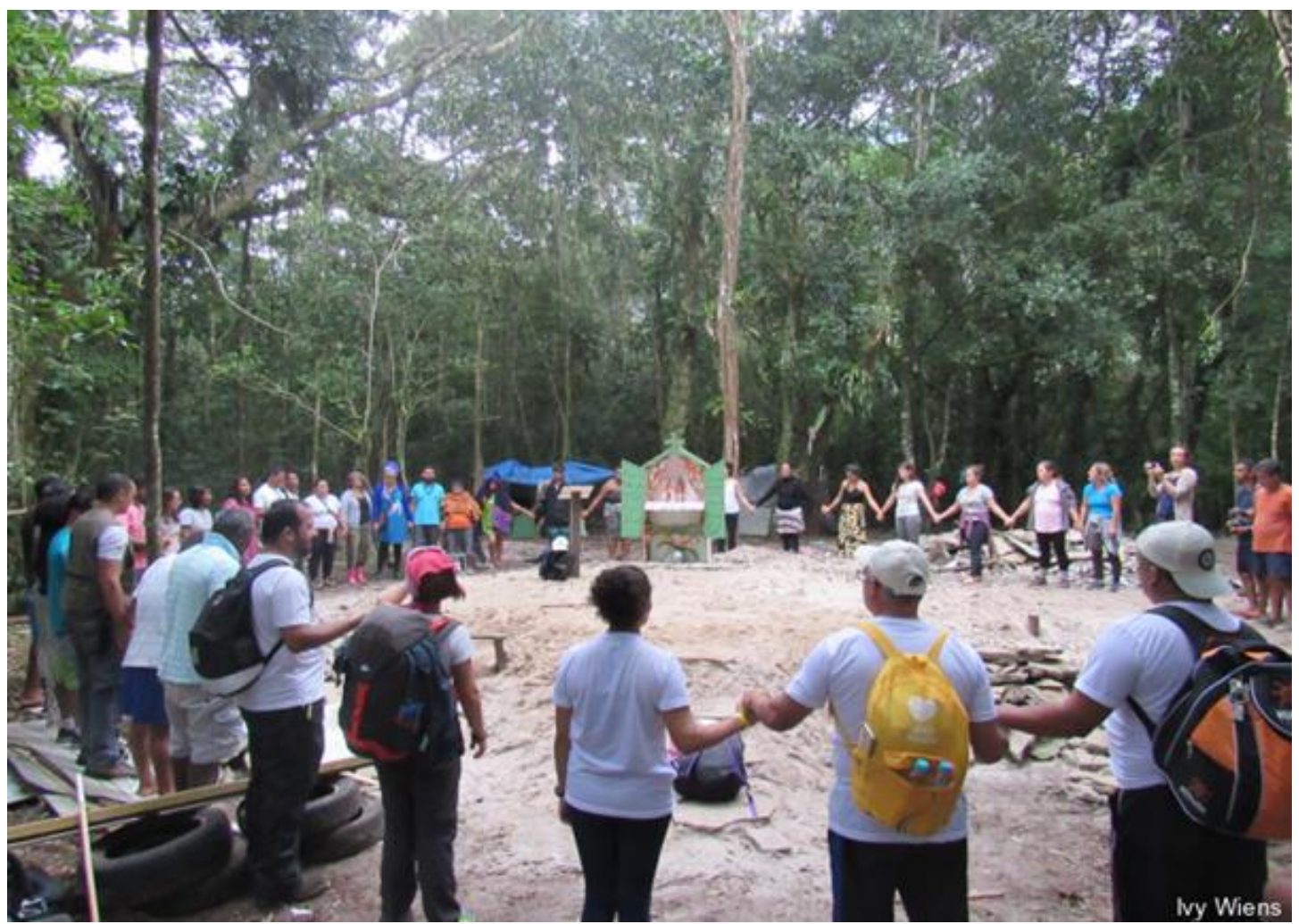

Fonte: Ivy Wiens. Disponível em: <https://www.socioambiental.org/pt-br/tags/jureia $>$. Acesso em: 06/10/2021.

Eles querem usufruir da emergente economia verde, pois muitos dos pseudo ambientalistas são grandes proprietários de fazendas produtoras de celulose e de outras monoculturas que rendem muito dinheiro.

Eles são bem intencionados economicamente em relação a Juréia, pois conforme o artigo publicado recentemente na revista Le Monde intitulado "tragédia e farsa no Rio Verde, um território caiçara na Juréia, percebe-se claramente que a Fundação Florestal "ao mesmo tempo em que expulsa caiçaras de território tradicional, a pretexto da proteção da natureza, entrega Unidades de Conservação de Proteção Integral à iniciativa privada, para a exploração de turismo empresarial de massa" (HAYAMA; DIEGUES; MARÉS; CUNHA, 2021).

Heber e Marcos são netos do casal Onésio do Prado e dona Nancy do Prado que habitam o território há três gerações conforme estudo antropológico de Plácido: 
A elaboração da árvore genealógica da família Prado revela pelo menos três gerações antecedentes ao Casal Onésio e Nancy do Prado até atingir os integrantes da família Prado identificados nos registros de terras. Logo, do ponto de vista da documentação textual, está plenamente comprovada a presença da família Prado na Juréia, e principalmente no Rio Verde, região onde hoje habita o casal Onésio e Nancy do Prado, e local da intervenção da Fundação Florestal. Do ponto de vista da documentação da cultura material, CALI (1999) identificou vestígios de casas da família Prado, em especial os sítios arqueológicos "Saltinho-01", "Saltinho02" e "Saltinho-03", sítios estes registrados no IPHAN - Instituto do Patrimônio Histórico e Artístico Nacional e cujos artefatos coletados encontram-se no Museu Histórico e Arqueológico de Peruíbe, sediado no prédio da Estação Ferroviária de Peruíbe. (PLÁCIDO, 2019, p. 15).

Embora os caiçaras comprovem sua permanência no território tanto pela presença física como cientificamente, por que a Fundação Florestal não dialoga com as famílias caiçaras da Juréia (Rio Verde e Grajaúna)? Por que não procura uma solução conjunta? Por que usa do autoritarismo? Por que não se preocupa em criar parcerias e projetos "efetivos" - não palestra- nas escolas para ensinar o que é uma unidade de conservação sobreposta a um território tradicional, como o caso da Juréia? Por que não há interesse de propagar a educação ambiental em parcerias com as comunidades e as escolas?

As respostas a essas indagações estão longe de ser obtidas com seriedade se forem vindas da Fundação Florestal, pois conforme reportagem da jornalista Natalia Ribas Guerrero, na coluna da UOL de Sakamoto, o "órgão ambiental alega que as construções eram irregulares e que a área em questão era desabitada. Laudos apontam ocupação caiçara de várias gerações" (GUERRERO, 2021). Para a Fundação Florestal o cientificamente correto é o que eles dizem e ponto final!

Aqui interessa uma consideração a respeito do ser caiçara histórico que resistiu à beira praia, durante a formação do povo brasileiro, - enquanto os colonizadores seguiram para o interior do continente em busca de riquezas - constituíram um jeito de ser que integra o saber do mar, da praia e da Mata Atlântica. Nesse território praiano desenvolveram um modo de viver, hoje chamado de sustentável, em harmonia com a fauna e a flora local. Respeitando o habitat natural, sempre promoveram o fandango de mutirão, o artesanato da caxeta, a medicação com ervas nativas, a construção de canoas de um pau só e outros tantos artefatos oriundos dos saberes de experiência que integra o repertório presente no Patrimônio Material e Imaterial.

Isolados em beira de rio, encosta de serras e na própria beira mar, os caiçaras foram e continuam sendo os principais protagonistas - guardiões da natureza - na manutenção e 
preservação da exuberante Mata Atlântica que compõe o Território Caiçara da Juréia, área sobreposta pela Estação Ecológica.

Retomando a lembrança, quando foi imposta a Unidade de Conservação (a estratégica Estação Ecológica da Juréia), os ambientalistas de gabinete - conhecidos pelos caiçara por pseudo ambientalistas - pesquisadores defensores da superada ideia de "Meio ambiente sem gente" iniciaram um processo de recolonização dessas populações litorâneas que ao longo dos séculos preservaram o mar, a praia, a mata e o ar. Quem não quer esse filé Mignon da Mata Atlântica?

\section{CONSIDERAÇÕES FINAIS}

[...] a modernidade veio junto com a colonialidade: a América não era uma entidade existente para ser descoberta. Foi inventada, mapeada, apropriada e explorada sob a bandeira da missão cristã. (MIGNOLO, 2017, p. 04).

Existe outra explicação que justifique a incisiva violência da Fundação Florestal sobre os casais de moradores da Juréia (Heber e Vanessa/Marcos e Daiane) senão o interesse capitalistas pela Mata Atlântica? A presença dessas duas famílias no território de origem incomoda os empresários da economia verde que enxergam na Juréia um potencial para explorar as essências vegetais e minerais que vão gerar lucro para suas empresas futuras. Os caiçaras incomodam no processo de privatização da Juréia.

Se os caiçaras não incomodassem, esses empresários que estão encastelados ou atrelados à Secretaria do Meio Ambiente do Estado de São Paulo, há mais de três décadas, já teriam feito uma parceria com os caiçaras, os verdadeiros guardiões da Mata Atlântica, que vivem há mais de 4 gerações no território conforme foi provado cientificamente por Cali Plácido em seu estudo realizado sobre a família do Sr. Onésio e Dona Nancy que habitam a comunidade do Rio Verde. Por que não se pode viver em seu território de origem mantendo a tradição do fandango, da pesca, do ajutório, dos preparos das comidas típicas, das festas?

É importante dizer que essa lógica de expulsão imposta pelo governo, por meio da Fundação Florestal, é a mando do capitalismo que se tornou um processo hegemônico, que no plano mundial se conecta com as estruturas de dominação para se manter e propagar-se. O capitalismo penetra e anima as instituições que produzem tentáculos da política neoliberal que no Brasil está em pleno curso. A política neoliberal aposta na permanência dos mais adaptados ao meio. Esconde-se numa 
retórica fascista. Faz parceria com a narrativa da exclusão. Promove a colonização dos indígenas, dos africanos e dos caiçaras.

Essa lógica colonial tem várias caras. Na Juréia ela se manifesta com o olhar do RACISMO AMBIENTAL. O racismo que prega para a sociedade a narrativa da preservação. Uma narrativa com verniz capitalista. Preserva-se a custo da expulsão, do silêncio, do cansaço e da inverdade. Em nome de uma preservação com interesses capitalistas - empresas interessadas na gestão da Estação Ecológica - a dita economia verde.

A destruição das casas dos casais caiçaras (Marcos/Daiane e Heber/Vanessa), pela Fundação Florestal, mostra bem essa lógica colonialista que atua historicamente e como está impregnada nas instituições sobretudo governamentais.

Os indígenas foram colonizados, os negros foram colonizados, meus pais foram colonizados com a queima da casa deles e as famílias de Marcos e Heber continuam sendo forçados à colonização.

Nesse ponto é possível responder as questões que propus anteriormente. A Fundação Florestal não dialoga com os moradores da Juréia (sobre a destruição das casas) porque quer colonizá-los. Atua autoritariamente porque quer colonizá-los. Não promove "efetivamente" Educação Ambiental nas escolas e nas comunidades porque quer colonizar o povo.

Como sair dessa colonização que chega silenciosamente e expulsa os nativos pelo cansaço? (CASTRO, 2017). Penso que seja por meio da reflexão e ampliação do debate popular entre as comunidades tendo como pauta a educação caiçara e o direito ao território.

Também é importante denunciar a forma como a Fundação Florestal age com as comunidades tradicionais e com os capitalistas poluidores do Vale do Ribeira. Em nota divulgada, os Anticapitalistas denunciam que os donos do capital sempre são protegidos:

Já viram alguma nota da Fundação Florestal citar o nome de Theodoro Konesuk, cunhado de Bolsonaro, que devastou uma vegetação de reserva legal às margens do Ribeira de Iguape? Ou já viram a SIMA citar em nota o nome de Rene Mariano, bananeiro do Vale do Ribeira que expandiu sua monocultura dentro do Parque Estadual da Caverna do Diabo? Ou mesmo já ouviram citar o nome do finado Antônio Ermírio de Moraes do Grupo Votorantim por quase desmatar grandes áreas no leito do Rio Ribeira de Iguape para a instalação de um complexo de quatro usinas hidrelétricas? Não viram, não vimos, nem veremos, pois os interesses envolvidos e o receio de mexer com interesses políticos empresariais não deixam. Esta "coragem" da FF só se vê contra caiçaras, quilombolas, 
ribeirinhos, indígenas e outras populações exploradas e excluídas dos privilégios desta sociedade, mas que moram dentro ou adjacente a unidades de conservação criadas a posteriori. ${ }^{2}$

O processo de descolonização das comunidades tradicionais caiçaras da Juréia, em especial do Rio Verde e Grajaúna, já vem acontecendo. Percebe-se pela consciência que os moradores já adquiriram em relação ao direito de viverem em seu território. Essa consciência permite a constante luta por uma vida feliz, saber o que é pescar uma garoupa e um parati nas pedras do costão do mar, saber o que é um fandango de mutirão, saber o que é reunir-se em torno do fogão à lenha e comer um belo pirão de peixe com farinha torrada, saber o que é criar uma criança no espaço da liberdade do mar, da praia e da mata, saber o que é ouvir estórias dos mais velhos ao pé do fogo, enfim... Saber o que é ser caiçara...

Assim, a descolonização caminha com a luta dos moradores da Juréia. Descolonizar, como dizia Paulo Freire, é, além de se superar da opressão é lutar para que o opressor também descolonize o seu próprio coração...

Os caiçaras da Juréia propõe uma solução com base na ciência e nos saberes da comunidade $^{3}$, essa proposta é a produção de um Plano de Uso Tradicional (PUT), elaborado em 2019, por pesquisadores em conjunto com as comunidades caiçaras da Juréia que se apresenta como,

uma solução para o conflito. Sendo assim, reiteramos nosso apoio a uma solução inovadora e alinhada com o estado da arte na área de conservação para a gestão da Estação Ecológica Juréia-Itatins, baseada em um modelo de governança adaptativa, construído de forma participativa e que envolva as comunidades tradicionais, o Estado, pesquisadores e outros atores sociais. Uma solução para o conflito da E.E.J.I. envolve a retomada do diálogo pela Fundação Florestal, a partir da discussão do Plano de Uso Tradicional (PUT) elaborado pela União dos Moradores da Juréia e a Associação dos Jovens da Juréia, com apoio de acadêmicos. Apresentado em junho de 2018 à Secretaria do Meio Ambiente do Estado de São Paulo, propõe um uso tradicional compatível com a conservação da biodiversidade e a preservação deste rico sistema socioecológico. (PUT, 2019).

\footnotetext{
${ }^{2}$ Nota dos Anticapitalistas sobre a ameaça aos Caiçaras do Rio Verde na Juréia. Disponível em: $<$ https://m.facebook.com/story.php?story_fbid=273464970986976\&id=106511101015698 >. Acesso em: $12 / 04 / 2021$.

${ }^{3}$ Disponível em: https://ajjureia.files.wordpress.com/2019/08/nota-de-esclarecimento-e-resposta-dospesquisadores_final_ago-2019.pdf
}

Rev. Iberoam. Patrim. Histórico-Educativo, Campinas (SP), v. 7, p. 1-16, e021007, 2021. 
O PUT é um documento construído em mutirão, onde pesquisadores e comunidades caiçaras trabalharam juntos para propor uma saída frente ao conflito (caiçara - Fundação Florestal) e um caminho para superar o racismo ambiental. Segue lista de pesquisadores que assinaram o PUT:

Carolina Santos Taqueda - Universidade de São Paulo,

Celia Regina T. Futemma - Universidade de Campinas,

Cristiana Simão Seixas - Universidade de Campinas,

Cristina Adams - Universidade de São Paulo,

Deborah Santos Prado - Universidade de Campinas,

Helena França - Universidade Federal do ABC,

Lucia Chamlian Munari - Universidade de Hohenheim,

Luciana Gomes de Araújo - Universidade de São Paulo,

Manuela Carneiro da Cunha - USP e Universidade de Chicago,

Mauro William B. de Almeida - Universidade de Campinas,

Rosely Alvim Sanches - Universidade de São Paulo.

\section{REFERÊNCIAS}

BRANDÃO, Carlos Rodrigues. O que é educação. São Paulo: Brasilienses, 2007. (Coleção primeiros passos, 2007).

CASTRO, Rodrigo Ribeiro de. Expulsão por cansaço e resistências: Etnografia das relações de poder no conflito territorial da Juréia (SP). Dissertação apresentada ao Instituto de Filosofia e Ciências Humanas (ICH) da Universidade Estadual de Campinas (UNICAMP) para título de mestre em Antropologia Social sob orientação de prof. Dr. Mauro William Barbosa de Almeida.

CUNHA, Manuela Carneiro da. O sistema sócio-ecológico da Juréia-Itatins: histórico de ocupação da região do Rio Verde, São Paulo. 2 de agosto de 2019. Disponível em:

<https://ajjureia.files.wordpress.com/2019/08/nota-de-esclarecimento-e-resposta-dospesquisadores final ago-2019.pdf>. Acesso em: 10 abr. 2021.

CUNHA, Manuela Carneiro da; DIEGUES, Antonio Carlos; HAYAMA, Andrew Toshio, Marés, Carlos. Tragédia e farsa no Rio Verde, um território caiçara na Juréia. Revista Le Monde Diplomatique-Brasil, 12 abr. 2021. Disponível em: <https://diplomatique.org.br/tragedia-efarsa-no-rio-verde-um-territorio-caicara-na- 
jureia/\#: :text=Na\%20regi\%C3\%A3o\%20da\%20Jureia\%2C\%20estado,de\%20Mata\%20At1\%C3 \%A2ntica\%20do\%20Brasil>. Acesso em: 15 abr. 2021.

DIEGUES, Antonio Carlos. O Vale do Ribeira e litoral de São Paulo: meio ambiente, história e população. (Texto originalmente preparado para o CENPEC). Disponível em: $<$ http://nupaub.fflch.usp.br/sites/nupaub.fflch.usp.br/files/color/cenpec.pdf >. Acesso em: 7 abr. 2021.

FORTES, Roberto. Iguape... Nossa História. Iguape: Gráfica Soset, 2000. v. 1.

FRANCO, Paulo Cesar. Oficinas de fandango caiçara como vivência de educação popular na Associação dos Jovens da Juréia-AJJ/Barra do Ribeira - Iguape - SP: Reafirmando o potencial das comunidades tradicionais caiçaras. 2015. 139 f. Dissertação - (Mestrado em Ciências Humanas) - Universidade Federal de São Carlos, Sorocaba, 2015.

FREIRE, Paulo. Pedagogia do oprimido. Rio de Janeiro: Paz e Terra, 1987.

GHANDI, Mahatma. Autobiografia - Minha vida e minhas experiências com a verdade. Tradução: Humberto Mariotti et al. São Paulo: Palas Atenas, 1999.

GUERRERO, Natalia Ribas. Caiçaras encaram batalha decisiva na Justiça por território na Juréia (SP). Leonardo Sakamoto, colunista da UOL (08/05/2021). Disponível em: <https://noticias.uol.com.br/colunas/leonardo-sakamoto/2021/05/08/caicaras-encaram-batalhadecisiva-na-justica-por-territorio-na-jureia-sp.htm>. Aceso em: 10 maio 2021.

MELO, Teresa Mary Pires de Castro. A floresta, a mesa e as leis: espaços, comunicação e mudança cultural em comunidade tradicional da Estação Ecológica Juréira-Itatins. 2000. Dissertação (Mestrado em Comunicação Social) - Universidade de São Paulo, 2002.

MIGNOLO, Walter D. Colonialidade: o lado mais escuro da modernidade. Tradução de Marco Oliveira. Revista Brasileira de Ciências Sociais [online]. 2017, v. 32, n. 94, e329402. Disponível em: < https://doi.org/10.17666/329402/2017. Acesso em:24/11/2021.

MUSEU VIVO DO FANDANGO. Alexandre Pimentel, Daniela Gramani, Joana Corrêa (Orgs.). Rio de Janeiro: Associação Cultural Caburé, 2006.

PEREIRA JUNIOR, Carlos Alberto (Org.). Iguape: princesa do litoral, terra do Bom Jesus, bonita por natureza. São Paulo: Noovha Américas, 2005.

PLÁCIDO, Cali. Carta aberta em defesa da família Prado e caiçaras da Juréia. Disponível em:

<https://www.socioambiental.org/sites/blog.socioambiental.org/files/blog/pdfs/carta_aberta_em defesa da familia prado - jureia 2019.pdf>. Acesso em: 8 maio 2021. 
PUPP, Cleonice Aparecida Franco. Entrevista concedida em 20 de setembro de 2021, Vila Nova, Iguape, SP.

PRADO, Dauro Marcos do. Entrevista concedida em novembro de 2020, na Barra do Ribeira, Iguape, SP.

RANGEL, Tauã Lima Verdan. Racismo ambiental às comunidades quilombolas. Revista Interdisciplinar de Direitos Humanos, Bauru, v. 4, n. 2, p. 129-141, jul./dez. 2016. Disponível em: <https://www3.faac.unesp.br/ridh/index.php/ridh/article/view/393/182>. Acesso em: 20/04/2021.

RIBEIRO, Darcy. O povo brasileiro: a formação e o sentido do Brasil. São Paulo: Companhia das Letras, 1995.

SANCHES, Rosely Alvim. Caiçaras e a Estação Ecológica de Juréia-Itatins: litoral sul de São Paulo. São Paulo: Annablume, Fapesp, 2004.

Recebido em: 08 de março de 2021

Aceito em: 09 de março de 2021 